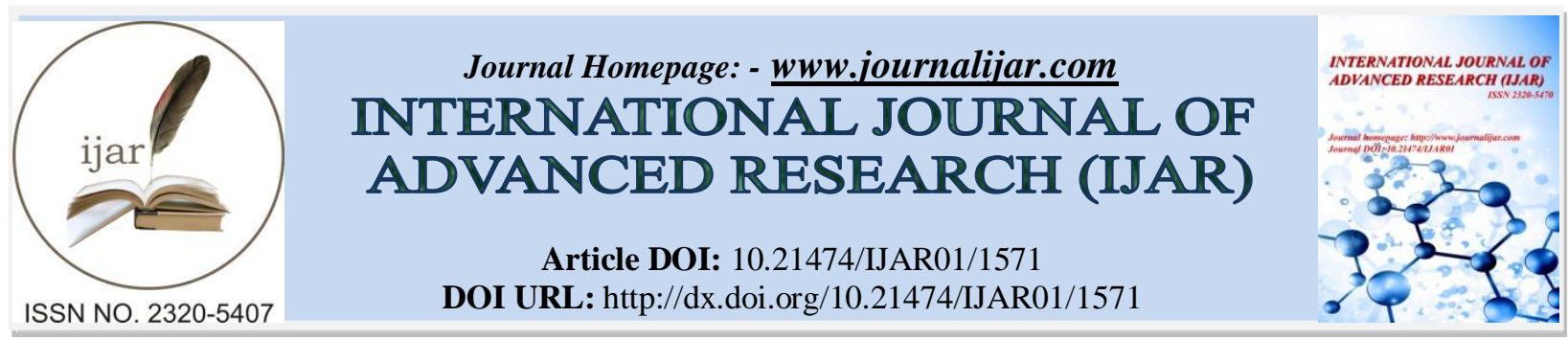

RESEARCH ARTICLE

\title{
AN INVESTIGATION OF AIR QUALITY AT THREE SELECTED LOCATIONS IN MALAYSIA FOR THE PERIOD OF 2009.
}

Wayan Suparta and Muhammad Afiq Mahat.

Space Science Centre (ANGKASA), Institute of Climate Change, Universiti Kebangsaan Malaysia, 43600, Bangi, Selangor Darul Ehsan, Malaysia.

\section{Manuscript Info}

Manuscript History

Received: 15 July 2016

Final Accepted: 22 August 2016

Published: September 2016

Key words:-

Air quality, Pollutants, Monsoon, Selected location in Malaysia.

\begin{abstract}
The rapid development of the urban and industrial area in several places in Malaysia has seriously increased the risk of air pollutions. Five major pollutants $\left(\mathrm{PM}_{10}, \mathrm{CO}, \mathrm{SO}_{2}, \mathrm{O}_{3}\right.$, and $\left.\mathrm{NO}_{2}\right)$ in 2009 were employed to study the trend and status of air quality at three selected locations in Malaysia, namely Klang, Petaling Jaya, and Kuala Lumpur. The data is then compared with the recommended of new Malaysian Ambient Air Quality Guidelines (MAAQG) standard and to determine the relationship between the trend and the sources of pollutions. Results showed that the concentration of $\mathrm{CO}, \mathrm{SO}_{2}$ and $\mathrm{NO}_{2}$ are obtained below the standard of MAAQG. The concentration of $\mathrm{PM}_{10}$ of all stations, however, exceeds the standard of MAAQG during June, July, and August due to the haze episode in 2009. The increasing trend during peak hour's shows by $\mathrm{CO}, \mathrm{SO}_{2}, \mathrm{NO}_{2}$ and $\mathrm{PM}_{10}$ is due to the traffic congestion. Klang recorded the highest of air pollution due to industrial activities which contributed to high pollutants level. The high diurnal trend showed by ozone $\left(\mathrm{O}_{3}\right)$ demonstrated that the formation of the gas is more influenced by sunlight in the photochemical process.
\end{abstract}

Copy Right, IJAR, 2016,. All rights reserved.

\section{Introduction:-}

The rapid progress of urban and industrial area in the development country such as Malaysia has led to high risk of environmental issues, particularly air pollution. Air pollution with its short and long term impact is a serious problem recognize by all over the world. The World Health Organization (WHO) reported that around 7 millions of people died in 2012 as a result of air pollution exposure. In Malaysia, air pollution was related to the increase rate of respiratory disease from the year 2008 to 2009 (Leh, 2012). The source of air pollution usually comes from motor vehicles, industrial and open burning. According to the Malaysian Department of the Environment (DOE 1996), motor vehicles contributed $82 \%$, power stations $9 \%$, industrial fuel burning $5 \%$, industrial production processes $3 \%$, domestic and commercial furnaces $0.2 \%$ and open burning at solid waste disposal sites $0.8 \%$ to the total of air emission load in the Malaysian Peninsula (Azmi et al., 2009).

In general, haze from Indonesian fires causes pollution spike in Malaysia. The main cause of this haze is the slash and burn practice by farmers and peat fires blown by the wind from Indonesia, especially Sumatra, which mainly affects the Peninsular Malaysia, Kalimantan and neighboring countries like Singapore. Another man made pollution 
in Malaysia is the growth of industrial and vehicle pollution which bring the increased greenhouse gasses. The trend of this pollution is occurring during the dry season. The Southwest Monsoon normally signifies relatively drier weather from late May to September. Another characterized weather in Malaysia is the Northeast Monsoon from November to March. The Northeast Monsoon brings heavy rainfall, particularly to the east coast states of Peninsular Malaysia and western Sarawak. Malaysia also experiences the transition period in between the monsoons is known as the intermonsoon period, where the first and the second intermonsoon will occur in April-May and in OctoberNovember every year, respectively. Barmpadimos et al. (2011) showed that during the southwest monsoon, the warmer air near the surface area rises to higher latitude, which causes the pollutants to become unstable, thus resulting in a high level of pollutants in the atmosphere.

The aim of this study is to investigate the status and trend of air quality in Malaysia, particularly in the three selected monitoring stations for the year 2009. These three locations recorded the highest pollutants every year. The air quality database is compared to the recommended Malaysian Ambient Air Quality Guidelines (MAAQG) and the factors that influenced the pollution trend is also evaluated.

\section{Methodology:-}

\section{A. Area of Study:-}

Three stations were selected for the purpose of this study. These three stations are located in Klang (CA0011: $03^{\circ} 00.620 \mathrm{~N}, 101^{\circ} 24.484 \mathrm{E}$ ), Petaling Jaya $\left(\mathrm{CA} 0016: 03^{\circ} 06.569 \mathrm{~N}, 101^{\circ} 38.329 \mathrm{~N}\right)$ and Kuala Lumpur (CA0054: $03^{\circ} 06.376 \mathrm{~N}, 101^{\circ} 43.072 \mathrm{E}$ ). Figure 1 shows the location of these three stations, which are located on the main road of high concentration of residential and industrial areas.

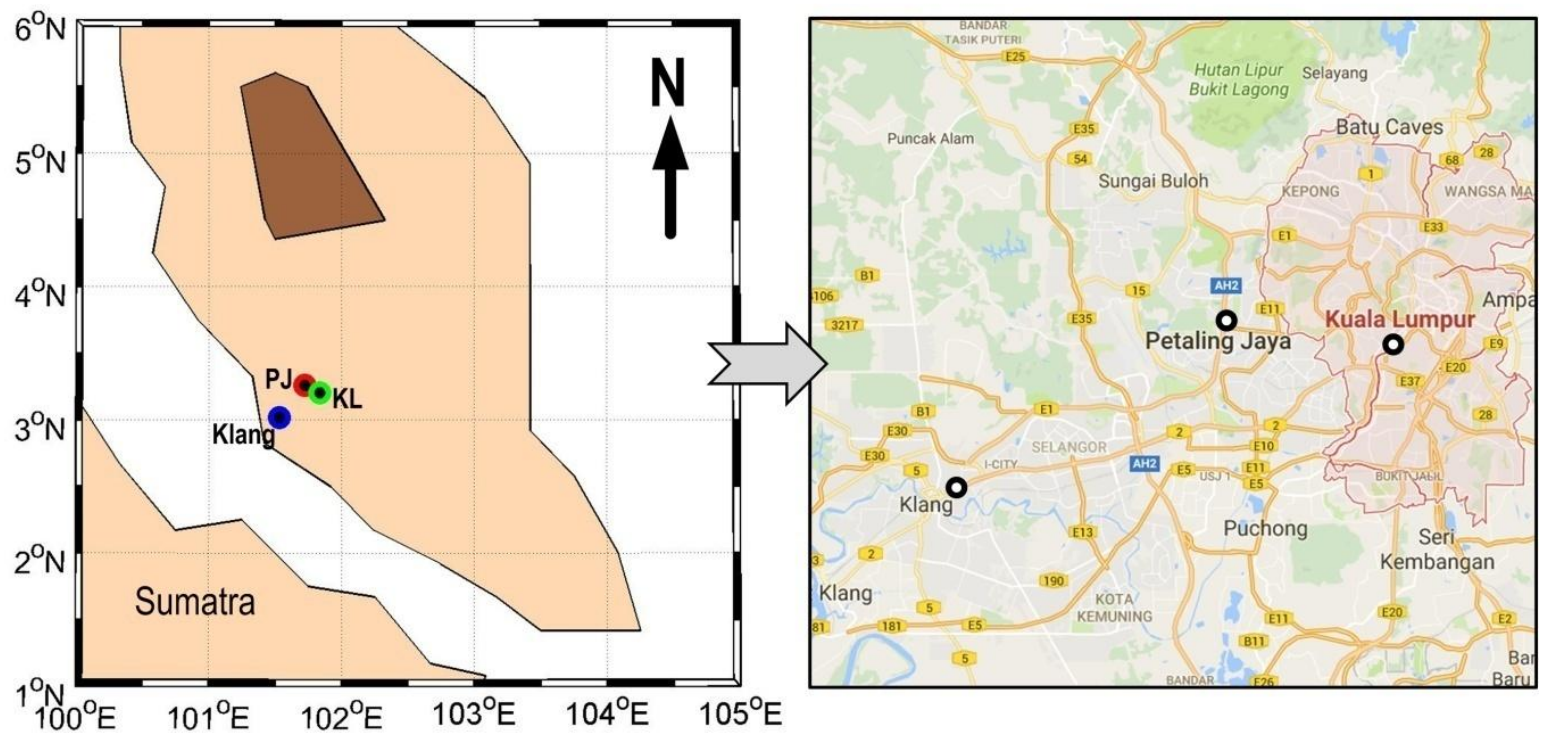

Fig. 1: The location of pollution observation in Peninsular Malaysia

\section{B. Air Quality Data:-}

The air quality level was monitored 24 hours a day by ground-based air quality monitoring stations. The air quality data used in this analysis was collected from January 2009 to December 2009. The parameters used in this analysis were carbon monoxide $(\mathrm{CO})$, nitrogen dioxide $\left(\mathrm{NO}_{2}\right)$, sulfur dioxide $\left(\mathrm{SO}_{2}\right)$, ozone $\left(\mathrm{O}_{3}\right)$ and particulate matter $\left(\mathrm{PM}_{10}\right)$. Meteorological parameters such as temperature and relative humidity are also recorded by the stations.

\section{Data Analysis:-}

The data collected from all three stations were then extracted and surpassed the quality process before analyzed. The concentration of $\mathrm{CO}, \mathrm{NO}_{2}, \mathrm{SO}_{2}, \mathrm{O}_{3}$, and $\mathrm{PM}_{10}$ are compared with MAAQG (Table 1) which are the new standard requirements for outdoor air quality. 
Table 1. New Malaysian Ambient Air Quality Standard Guidelines (DOE, 2013)

\begin{tabular}{|l|c|c|c|c|}
\hline \multicolumn{1}{|c|}{ Pollution } & $\begin{array}{c}\text { Averaging } \\
\text { Time }\end{array}$ & \multicolumn{3}{|c|}{ Ambient Air Quality Standard } \\
\cline { 3 - 5 } & & $\begin{array}{c}\text { IT-1 (2015) } \\
\mu \mathrm{g} / \mathrm{m}^{3}\end{array}$ & $\begin{array}{c}\text { IT-2 (2018) } \\
\mu \mathrm{g} / \mathrm{m}^{3}\end{array}$ & $\begin{array}{c}\text { Standard (2022) } \\
\mu \mathrm{g} / \mathrm{m}^{3}\end{array}$ \\
\hline Carbon monoxide $(\mathrm{CO})^{* *}$ & 1 hour & 35 & 35 & 30 \\
& 8 hour & 10 & 200 & 10 \\
\hline Ground Level Ozone $\left(\mathrm{O}_{3}\right)$ & 1 hour & 200 & 120 & 100 \\
\hline Nitrogen Dioxide $\left(\mathrm{NO}_{2}\right)$ & 8 hour & 120 & 300 & 280 \\
& 1 hour & 320 & 75 & 70 \\
\hline Sulfur Dioxide $\left(\mathrm{SO}_{2}\right)$ & 24 hour & 75 & 300 & 250 \\
& 24 hour & 350 & 40 & 80 \\
\hline Particulate matter with the size of & 1 hour & 50 & 120 & 40 \\
less than 10 micron $\left(\mathrm{PM}_{10}\right)$ & 24 hour & 150 & 25 & 100 \\
\hline Particulate Matter with the size of & 1 hour & 35 & 50 & 15 \\
less than 2.5 micron $\left(\mathrm{PM}_{2.5}\right)$ & 24 hour & 75 & & 35 \\
\hline
\end{tabular}

Note: $* * \mathrm{mg} / \mathrm{m}^{3}$

The new additional parameter which is particulate matter with the size of less than 2.5 micron $\left(\mathrm{PM}_{2.5}\right)$.The air pollutants concentration limit will be strengthen in stages until 2020. To strengthen the analysis, the average ambient temperature and relative humidity are compared with the dry season in June, July and August 2009. The hourly trend of air pollutants is also investigated to find the sources of air pollutions. Only significant results were taken into considerations as to simplify the process of analysis.

\section{Results and discussion:-}

Figure 2 illustrates the one-hour average concentration of $\mathrm{CO}$ for all three selected stations. The results showed that the concentration of $\mathrm{CO}$ recorded in all stations is way below the standard of MAAQG. From the figure, we can see that at Petaling Jaya and Kuala Lumpur, the concentration average of CO was higher during March-April, JuneAugust (dry season) and November-December, while at Klang the CO concentration only high during the dry season. Petaling Jaya is about $30 \mathrm{~km}$ from Klang or about $20 \mathrm{~km}$ from Kuala Lumpur. In other words, the distance from Kuala Lumpur to Klang is about $40 \mathrm{~km}$ (see Fig. 1). Klang is the highest polluted area due to industrial and man-made activities and the highest concentration $(8.5 \mathrm{ppm})$ recorded was in June 2009. The other two stations recorded less than $6.0 \mathrm{ppm}$ along the year 2009. Same results showed by $\mathrm{NO}_{2}$ and $\mathrm{SO}_{2}$ where the concentration recorded by all three stations is below the standard of MAAQG. 

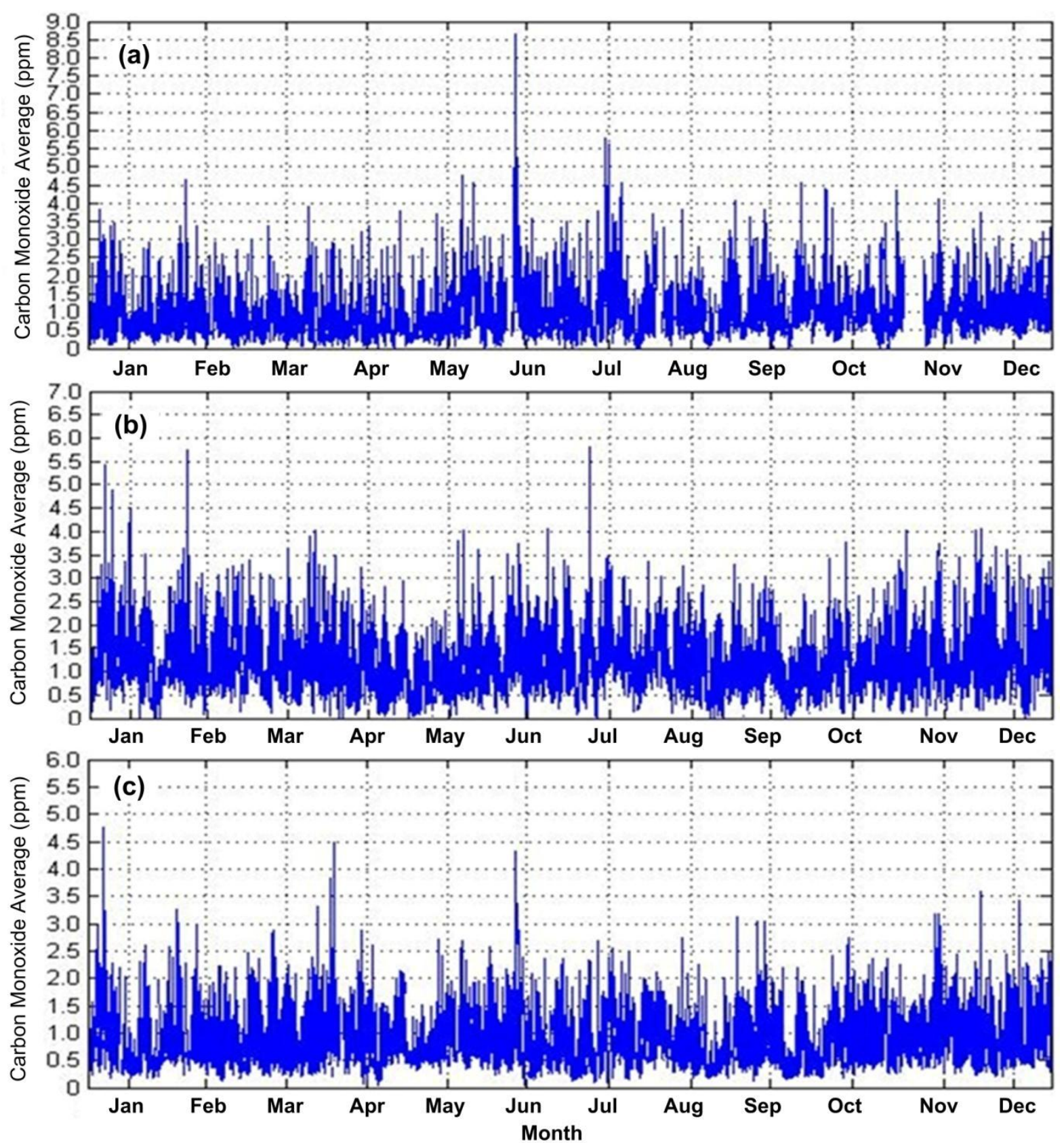

Fig. 2: Concentration of CO variation on one-hour average for the year 2009 at (a) Klang (CA0016), (b) Petaling Jaya (CA0011), and (c) Kuala Lumpur (CA0054)

Figure 3 shows the daily average concentration of $\mathrm{PM}_{10}$ for Klang station for the year 2009. In Klang, $\mathrm{PM}_{10}$ exceed the standard of MAAQG between June and August 2009. According to Malaysia environmental quality report 2009, this was due to haze episodes between June and August 2009 (Rahman et al., 2015). Southwest monsoon wind transported the suspended particulate $\mathrm{PM}_{10}$ from Sumatra to the west coast of Peninsular Malaysia, which resulted in severe haze conditions in Klang and Kuala Selangor. For the other two stations, the concentration of $\mathrm{PM}_{10}$ is still under control that was below the standard of MAAQG. 


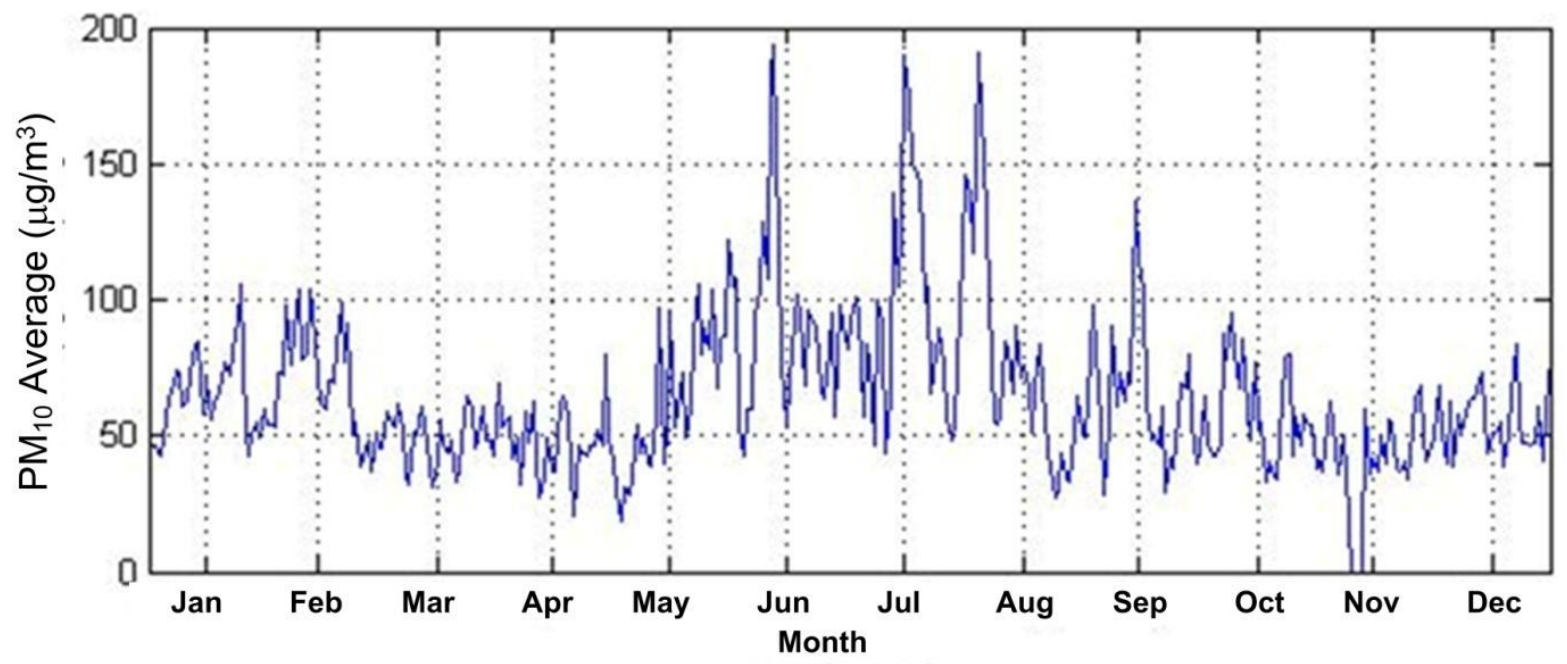

Fig. 3: Hourly average of $\mathrm{PM}_{10}$ concentration for the year 2009 at Klang station

Although the other two stations for $\mathrm{PM}_{10}$ still maintain with below the standard MAAQG, the concentration still shows an increment during June, July, and August. The Same trend was showed by other parameters where the concentration is increased during these months. It was due to the southwest monsoon or dry season. The Southwest monsoon normally signifies relatively drier weather. It can be proved from the ambient temperature and relative humidity that during June, July, and August, the humidity is drop and the temperature is increased. The opposite relationship of these two parameters is common for the weather in Malaysia (Suparta et al., 2016a). From the figure, we can see that relative humidity at Kuala Lumpur (KL) is 15\% higher compared to humidity at Klang, or 10\% higher compared to humidity at Petaling Jaya (PJ). Kuala Lumpur as a center of business is crowded by the number of vehicles in each day. The city also received unstable weather from other nearby places.

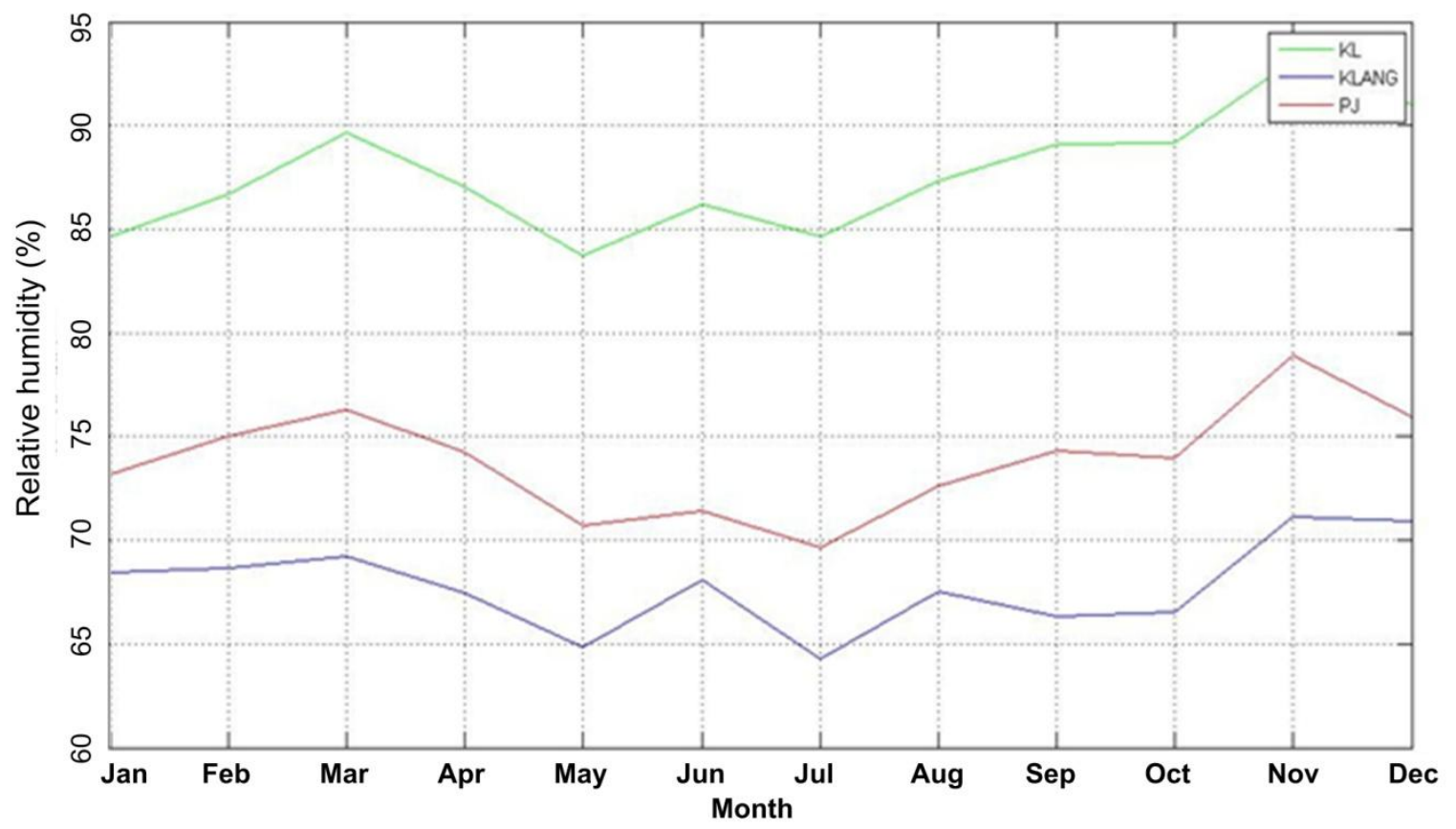

Fig. 4: Average relative humidity for the period of 2008 at three selected stations

To investigate the trend of pollutants during the period of 2009, daily air pollution is plotted as in Figure 5. As shown in the figure, the diurnal trend of $\mathrm{CO}, \mathrm{NO}_{2}, \mathrm{SO}_{2}, \mathrm{O}_{3}$, and $\mathrm{PM}_{10}$ for all three stations show a similar trend where the concentration of these four pollutants is increased from 7am to 9am and 5pm onward. This increment trend was due to the traffic congestion during peak hours (Azmi et al., 2009). Azmi et al. (2009) also observed that 
high CO concentration is considered to correlate directly with the number of motor vehicles. The Ministry of Transport Malaysia reported that there are about 19.02 million of registered vehicles in 2009 (Abdullah et al., 2012). Petaling Jaya station is recorded as the highest concentration compared to other two stations for CO. As for $\mathrm{NO}_{2}$ and $\mathrm{SO}_{2}$, the source of this gas usually comes from motor vehicles. Moreover, industrial processes and open burning also contributed to high pollutant level. Klang station shows to the highest concentration of $\mathrm{PM}_{10}$ compared to others because there are many large factories active.
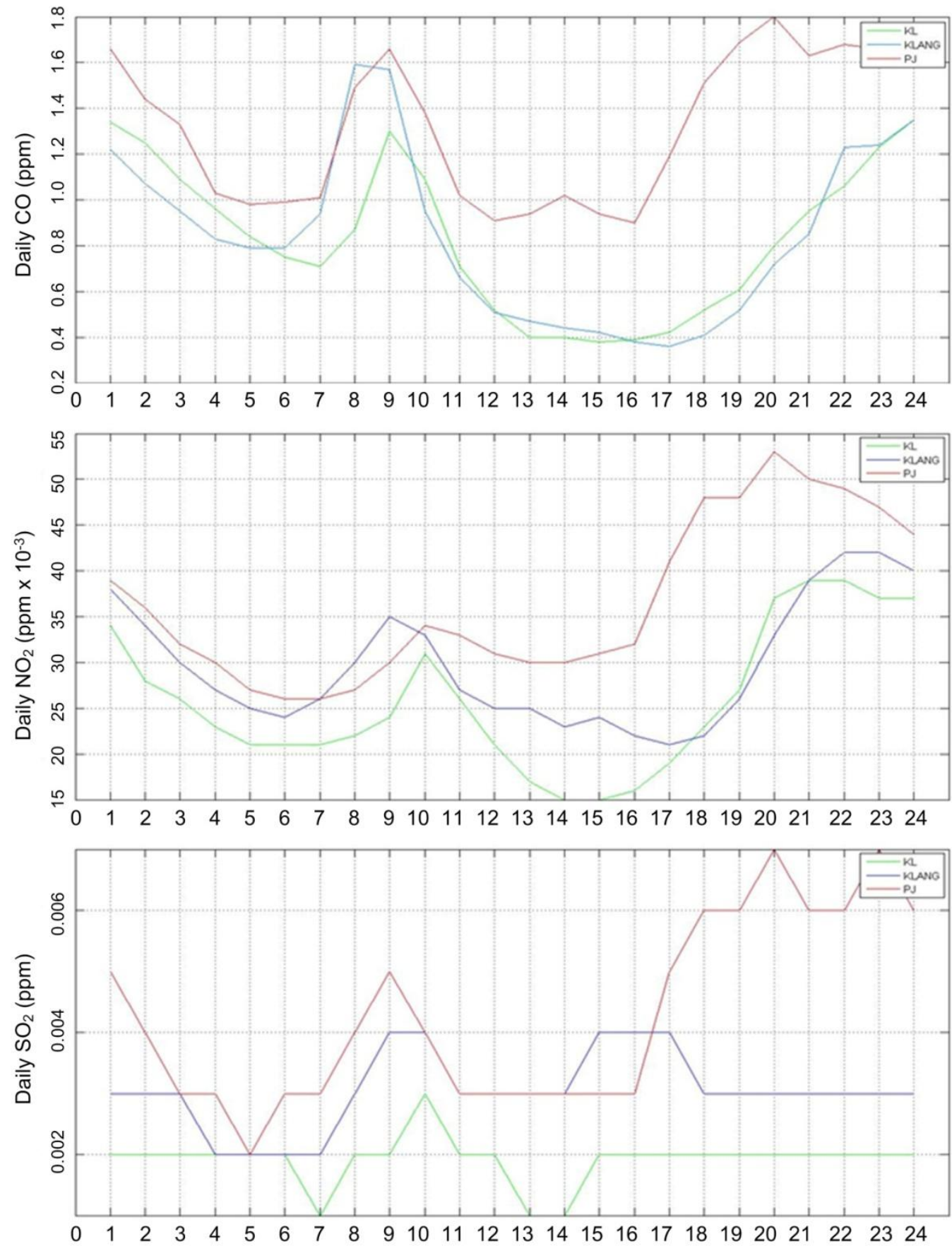

Fig. 5: Daily trend pollutants for $\mathrm{CO}, \mathrm{NO}_{2}$ and $\mathrm{SO}_{2}$ for the period of 2009 at three selected stations

The home with the busiest and biggest port in Malaysia is Port Klang, which possibly contributes to the heavy traffic congestion from the Port. Figure 6 shows the $\mathrm{PM}_{10}$ and $\mathrm{O}_{3}$ trend for the three selected locations. Department of Environmental (2008) reported that the high of $\mathrm{PM}_{10}$ was due to the hot and dry weather. The different trend shows 
by $\mathrm{O}_{3}$ where the concentration started to increase from $9 \mathrm{am}$ to $2 \mathrm{pm}$, then, the concentration decrease from $3 \mathrm{pm}$ onward. The month of April recorded the highest concentration $\mathrm{O}_{3}$ with $0.047 \mathrm{ppm}$, followed by October with value of $0.041 \mathrm{ppm}$ (Suparta et al., 2016b). The highest concentration was recorded by Klang station while the lowest was found at Petaling Jaya station. The trend demonstrates that the gas is influenced by sunlight through photochemical factor (Sillman, 1999). Geddes (2009) found that meteorological factors such the local temperature would also have the ability to increase the concentration of ozone in the atmosphere.
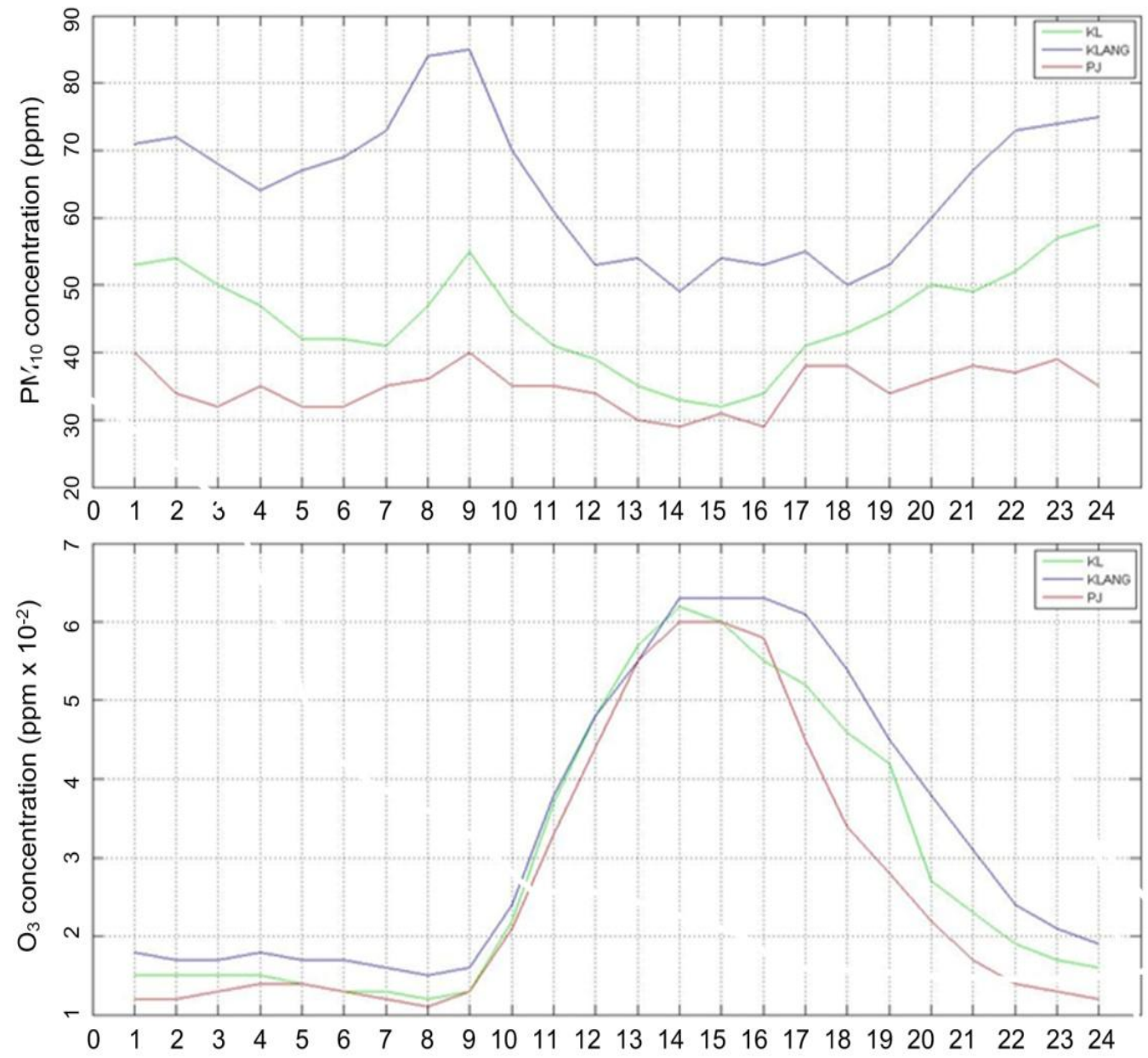

Fig.6: Daily trend pollutants for $\mathrm{PM}_{10}$ and $\mathrm{O}_{3}$ for the period of 2009 at three selected stations

\section{Conclusion:-}

This study has successfully conducted the investigation of air pollution trend in the three selected location in Malaysia. The results showed that the average concentration of $\mathrm{CO}, \mathrm{NO}_{2}$, and $\mathrm{SO}_{2}$ recorded are under the permissible value. Since Malaysia is characterized by two monsoons which are Southwest monsoon from late May to September, and the Northeast monsoon from November to March, the southwest monsoon brings the high concentration of all pollutants during month June, July, and August. All atmospheric pollutants except ozone shows an increasing trend during peak hours mostly influence by motor vehicles and industrial processes. Hot and dry weather is another possible factor contributes in high of $\mathrm{PM}_{10}$. The anomaly diurnal trend shown by ozone is because of sunlight through photochemical reactions and meteorological factors such as influenced by local temperature.

\section{Acknowledgments:-}

This research is supported by university grant under Rewards Publications: GP-K017155. The authors would like to thank the Department of Environment Malaysia (DoE) for providing the API data. 


\section{References:-}

1. Abdullah, A. M., Samah, M. A. A., and Tham, Y. J. (2012): An Overview of the Air Pollution Trend in Klang Valley, Malaysia. Department of Environmental Science, Faculty of Environmental Studies, Universiti Putra Malaysia, 43400 Serdang, Selangor, Malaysia.

2. Azmi, S. Z., Latif, M. T., Ismail, A. S., Juneng, L., and Jemain, A. A. (2009): Trend and Status of Air Quality at Three Different Monitoring Stations in the Klang Valley, Malaysia. Air Qual. Atmos. Health, 3:53-64.

3. Barmpadimos, I., Hueglin, C., Keller, J., Henne, S., and Prevot, A. S. (2011): Influence of Meteorology on $\mathrm{PM}_{10}$ Trends and Variability in Switzerland from 1991 to 2008. Atmos. Chem. Phys., 11: 1813-1835.

4. Department of Environment (DOE), 2008: Malaysia Environmental Quality Report 2008, Malaysia: Department of Environment.

5. DOE (2013): New Malaysia Ambient Air Quality Standard, http://www.doe.gov.my/portalv1/wpcontent/uploads/2013/01/Air-Quality-Standard-BI.pdf

6. Leh, O. L. H., Ahmad, S., Aiyub, S., Jani, Y. M., and Hwa, T. K. (2012): Urban Air Environmental Health Indicators for Kuala Lumpur City. Sains Malaysiana, 41(2): 179-191.

7. Rahmah, S. R. A. , Ismail, S. N. S.., Ramli, M. F., Latif, M. T., Abidin, E. Z., and Praveena, S. M. (2015): The Assessment of Ambient Air Pollution Trend in Klang Valley, Malaysia. World Environ., 5(1): 1-11.

8. Sillman, S. (1999):The Relation Between Ozone, $\mathrm{NO}(\mathrm{X})$ and Hydrocarbons in Urban and Polluted Rural Environments. Atmos. Environ., 33: 1821-1845.

9. Suparta, W., Muhammad, M., Singh, M. S. J., Tangang, F. T., Abdullah, M., and Islam, M. T. (2016a): Variability of GPS Water Vapor Associated with Warming Activity in Peninsular Malaysia during the Period of 2008 - 2011. Journal of Water and Climate Change, 7(1): 240-250.

10. Suparta, W., Alhasa, K. M., Singh, M. S. J., and Latif, M. T. (2016b): The Development of PWV Index for Air Pollution Concentration Detection in Banting, Malaysia. 2015 International Conference on Space Science and Communication (IconSpace), Langkawi, Malaysia, 10-12 August 2015, p. 498-502. 